\title{
Molecular Characterization of Boscalid Resistance in Field Isolates of Botrytis cinerea from Apple
}

\author{
Y. N. Yin, Y. K. Kim, and C. L. Xiao
}

First author: Department of Plant Pathology, Washington State University, Tree Fruit Research and Extension Center, Wenatchee 98801, and Institute of Biotechnology, Zhejiang University, Hangzhou, China; and second and third authors: Department of Plant Pathology, Washington State University, Tree Fruit Research and Extension Center, Wenatchee. Accepted for publication 25 March 2011.

\begin{abstract}
Yin, Y. N., Kim, Y. K., and Xiao, C. L. 2011. Molecular characterization of boscalid resistance in field isolates of Botrytis cinerea from apple. Phytopathology 101:986-995.

Botrytis cinerea isolates obtained from apple orchards were screened for resistance to boscalid. Boscalid-resistant $\left(\operatorname{Bos}^{\mathrm{R}}\right)$ isolates were classified into four phenotypes based on the levels of the concentration that inhibited fungal growth by $50 \%$ relative to control. Of the 220 isolates tested, 42 were resistant to boscalid, with resistant phenotypes ranging from low to very high resistance. There was cross resistance between boscalid and carboxin. Analysis of partial sequences of the ironsulfur subunit of succinate dehydrogenase gene in B. cinerea $(B c S d h B)$ from $13 \mathrm{Bos}^{\mathrm{R}}$ and 9 boscalid-sensitive $\left(\mathrm{Bos}^{\mathrm{S}}\right)$ isolates showed that point mutations in $B c S d h B$ leading to amino acid substitutions at the codon position 272 from histidine to either tyrosine (H272Y) or arginine (H272R) were correlated with boscalid resistance. Allele-specific polymerase chain reaction (PCR) analysis of $66 \mathrm{Bos}^{\mathrm{R}}$ isolates (including 24

but $1 \mathrm{Bos}^{\mathrm{R}}$ isolate gave no amplification product. Analysis of the $B c S d h B$ sequence of this isolate revealed a different point mutation at codon 225, resulting in a substitution of proline $(\mathrm{P})$ by phenylalanine $(\mathrm{F})(\mathrm{P} 225 \mathrm{~F})$. The results indicated that $\mathrm{H} 272 \mathrm{R} / \mathrm{Y}$ in $B c S d h B$ were the dominant genotypes of mutants in field $\mathrm{Bos}^{\mathrm{R}}$ isolates from apple. A multiplex allele-specific PCR assay was developed to detect point mutations $\mathrm{H} 272 \mathrm{R} / \mathrm{Y}$ in a single PCR amplification. Levels of boscalid resistance ranged from low to very high within isolates carrying either the H272R or $\mathrm{H} 272 \mathrm{Y}$ mutation, indicating that, among $\mathrm{Bos}^{\mathrm{R}}$ isolates, different $\mathrm{Bos}^{\mathrm{R}}$ phenotypes (levels of resistance) were not associated with particular types of point mutations (H272R versus $\mathrm{H} 272 \mathrm{Y}$ ) in $B c S d h B$. Analysis of genetic relationships between $39 \mathrm{Bos}^{\mathrm{R}}$ and $56 \mathrm{Bos}^{\mathrm{S}}$ isolates based on three microsatellite markers showed that $39 \mathrm{Bos}^{\mathrm{R}}$ isolates and $30 \mathrm{Bos}^{\mathrm{S}}$ isolates were clustered into two groups, and the third group consisted of only Bos $^{S}$ isolates, suggesting that the development of resistance to boscalid in $B$. cinerea likely is not totally random, and resistant populations may come from specific genetic groups.
\end{abstract} additional isolates obtained from decayed apple fruit) showed that 19 carried the point mutation $\mathrm{H} 272 \mathrm{Y}$ and 46 had the point mutation $\mathrm{H} 272 \mathrm{R}$,
Additional keywords: carboxamide, fungicide resistance, SDHI fungicides.
Botrytis cinerea Pers. (teleomorph Botryotinia fuckeliana (de Bary) Whetzel) causes pre- and postharvest diseases in many economically important crops, including vegetable, fruit, and ornamental plants (17). Synthetic fungicides remain the major tools for control of Botrytis cinerea (21). However, B. cinerea is a high-risk pathogen for the development of fungicide resistance because of its short life cycle and prolific reproduction (6). Resistance of $B$. cinerea to fungicides negatively affects control efficacy and often results in the failure of disease control (21).

Gray mold caused by $B$. cinerea is a major postharvest fruit rot disease of apple. Control of gray mold in stored apple fruit can be achieved by applying fungicides either near harvest in the orchard or after harvest as a postharvest treatment (30). The boscalidcontaining product Pristine (BASF Corporation, Research Triangle Park, NC), a premixed formulation of boscalid and pyraclostrobin, was registered in 2005 for use on apple in the United States. Application of Pristine within 2 weeks before harvest is effective in controlling gray mold in stored apple fruit, and this practice is being increasingly implemented since 2005 by apple growers and packers for control of gray mold and other postharvest diseases in stored apple fruit (30). However, resistance to boscalid was observed in $B$. cinerea isolates obtained from gray mold-decayed, stored apple fruit originating from apple orchards where Pristine had been used in each of the four consecutive

Corresponding author: C. L. Xiao; E-mail address: clxiao@wsu.edu

doi:10.1094/PHYTO-01-11-0016

(c) 2011 The American Phytopathological Society years since 2005 (19). Although the vast majority of boscalidresistant $\left(\operatorname{Bos}^{\mathrm{R}}\right)$ isolates obtained from stored apple fruit also are resistant to pyraclostrobin, there is no cross resistance between boscalid and pyraclostrobin, suggesting that boscalid resistance is a result of selection pressure from the use of the boscalidcontaining fungicide Pristine in apple orchards (19). However, there is no information available about the frequency of $\mathrm{Bos}^{\mathrm{R}}$ isolates in apple orchards where the fungicide had been used (19).

Boscalid is a recently introduced fungicide belonging to the class of succinate dehydrogenase inhibitors (SDHIs). In addition to boscalid, SDHIs also include other compounds such as carboxin and flutolanil (10), which have similar chemical structures and modes of action $(16,28)$. The target site of SDHIs is succinate ubiquinone reductase or succinate dehydrogenase (SDH) complex, which is a functional part of the tricarboxylic acid cycle and the mitochondrial electron transport chain (18). The SDH complex consists of four subunits; that is, a flavoprotein (Fp) subunit $(\mathrm{SdhA})$; an iron-sulfur protein (Ip) subunit (SdhB), including three iron-sulfur clusters; and two membrane-anchored protein subunits (SdhC and SdhD) $(11,16)$. Previous studies have documented that the SDH binding site is composed of the residues in subunits of $\mathrm{SdhB}, \mathrm{SdhC}$, and $\mathrm{SdhD}$ and is highly conserved in bacteria and eukaryotes $(13,14,29)$.

Substitutions of conserved amino acids in the SDH complex conferring resistance to SDHI fungicides have been reported in various microorganisms $(2-4,7,12,15,16,26-28)$. In most cases, single-point mutations correlating with SDHI resistance commonly occur on a highly conserved histidine residue located in the third cysteine-rich cluster in the SdhB subunit. In B. cinerea, 
laboratory $\operatorname{Bos}^{\mathrm{R}}$ mutants can be readily obtained by UV mutagenesis $(8,28,31)$. Molecular analyses based on lab mutants and field-resistant isolates indicated mutations at the amino acid positions of $272(\mathrm{H} 272 \mathrm{Y} / \mathrm{R})$ and $225(\mathrm{P} 225 \mathrm{~L} / \mathrm{F} / \mathrm{T})$ in $B c S d h B$ correlating with boscalid resistance $(8,28)$. More recently, Leroux et al. (22) reported that, in addition to mutations H272Y/R, single-point mutations $\mathrm{H} 272 \mathrm{~L}$ and $\mathrm{N} 230 \mathrm{I}$ in $B c S d h B$ and H132R in $B c S d h D$ were also correlated with boscalid resistance in $B$. cinerea isolates obtained from infected berries in France and Germany; however, the latter three mutations were much less common in the field. Stammler (28) reported that mutations $\mathrm{H} 272 \mathrm{Y}$ and $\mathrm{P} 225 \mathrm{~L} / \mathrm{F}$ in the $B c S d h B$ gene were associated with significantly reduced sensitivities to boscalid in $B$. cinerea, whereas the reduction in sensitivity was less pronounced in isolates carrying mutations $\mathrm{H} 272 \mathrm{R}$ and P225T. However, no detailed information, such as frequency of resistant phenotypes and genotypes as well as their ranges of the concentration that inhibits fungal growth by $50 \%$ relative to control ( $\mathrm{EC}_{50}$ values), was provided in the report (28). It remains to be determined whether different phenotypes of boscalid resistance (levels of resistance) are associated with particular types of point mutations in $B c S d h B$ among $B^{\mathrm{R}}$ isolates of $B$. cinerea.

The objectives of this study were to (i) assess the frequency of $\operatorname{Bos}^{\mathrm{R}}$ isolates in $B$. cinerea populations collected from apple orchards where the fungicide had been used, (ii) determine whether there is cross-resistance between boscalid and carboxin, (iii) characterize mutations in the $\mathrm{SdhB}$ subunit of SDH correlating with boscalid resistance and determine whether Bos $^{\mathrm{R}}$ phenotypes (levels of resistance) in field-resistant isolates of $B$. cinerea are associated with particular types of point mutations in the $B c S d h B$ gene, (iv) develop polymerase chain reaction (PCR) assays for molecular diagnosis of boscalid resistance, and (v) assess genetic relationships between $\operatorname{Bos}^{\mathrm{R}}$ and boscalid-sensitive $\left(\mathrm{Bos}^{\mathrm{S}}\right)$ isolates of $B$. cinerea from apple.

\section{MATERIALS AND METHODS}

Frequency of boscalid resistance in apple orchards treated with Pristine. To determine frequency of $\mathrm{Bos}^{\mathrm{R}} B$. cinerea isolates in apple orchards, 'Gala' apple fruit were sampled in August and September 2009 before harvest from five orchards located in Brewster, WA. In these orchards, the boscalid-containing fungicide Pristine had been used in each of the four consecutive years since 2005, and boscalid resistance had been detected in $B$. cinerea isolates recovered from decayed apple fruit originating from the 2008 crops from these orchards (19). In each orchard, 102 symptomless Gala apple fruit were hand picked from 34 trees ( 3 fruit per tree). To isolate $B$. cinerea from the fruit, the stem and floral parts of each fruit were excised, briefly rinsed with sterile water, and air dried on sterilized paper in a laminar-flow hood. Tissues were placed on acidified potato dextrose agar (APDA) (Difco Laboratories, Detroit) (4 $\mathrm{ml}$ of a $25 \%$ lactic acid per liter of medium) in petri dishes. Plates were incubated at $20^{\circ} \mathrm{C}$ in the dark and examined for culture development. Fungal colonies similar to those of B. cinerea on isolation plates were transferred onto fresh APDA. Pure cultures were then grown on PDA and inoculated at $20^{\circ} \mathrm{C}$ under $12 \mathrm{~h}$ of light and $12 \mathrm{~h}$ of darkness to facilitate sporulation. $B$. cinerea isolates were then single-spore cultured and mycelium plugs were stored in $15 \%$ glycerol at $-80^{\circ} \mathrm{C}$. In total, 220 single-spore isolates of $\mathrm{B}$. cinerea were obtained from these five orchards (Table 1).

Technical-grade boscalid (99\% a.i.) (BASF Corporation) was dissolved in $100 \%$ acetone to provide stock solutions containing $25 \mathrm{mg} / \mathrm{ml}$. Sensitivity of conidial germination to boscalid was tested on $2 \%$ water agar (WA) amended with boscalid at the minimum inhibitory concentration (MIC) level $(5 \mu \mathrm{g} / \mathrm{ml})$ following the procedure of Kim and Xiao (19). Isolates that were able to germinate were considered resistant to boscalid, whereas those that were not able to germinate were classified as Bos ${ }^{\mathrm{S}}$ isolates.

Phenotypes of $\mathbf{B o s}^{\mathbf{R}}$ isolates. In total, $172\left(66 \mathrm{Bos}^{\mathrm{R}}\right.$ and 106 Bos $^{\mathrm{S}}$ ) B. cinerea isolates were included in this study. Of these isolates, $42 \mathrm{Bos}^{\mathrm{R}}$ (Table 2) and $54 \mathrm{Bos}^{\mathrm{S}}$ isolates came from the 220 single-spore isolates obtained in 2009 from five apple orchards as described above. The remaining $24 \mathrm{Bos}^{\mathrm{R}}$ and $52 \mathrm{Bos}^{\mathrm{S}}$ isolates were obtained during 2001 to 2009 from decayed apple fruit originating from orchards in the main apple-production areas in central Washington (19). All isolates used in this study were single-spore cultured.

For all $\mathrm{Bos}^{\mathrm{R}}$ isolates, $\mathrm{EC}_{50}$ values of boscalid were determined in a conidial germination assay following the procedure of Kim and Xiao (19), and the experiment was performed twice. Stock solutions of technical-grade boscalid or a formulated boscalid (Endura $70 \%$ a.i.; BASF Corporation) were added into $2 \%$ WA to produce concentrations of boscalid in the medium of $0,1,2.5,5$, $10,20,63.1,189.3$, and $631 \mu \mathrm{g} / \mathrm{ml}$. The formulated product was used to make higher concentrations of boscalid $(>20 \mu \mathrm{g} / \mathrm{ml})$ in the medium because of limited solubility of technical-grade boscalid in acetone (19). In the boscalid baseline sensitivity study for $B$. cinerea populations from apple in Washington State, the mean $\mathrm{EC}_{50}$ value of boscalid was $0.631 \mu \mathrm{g} / \mathrm{ml}$ for Bos ${ }^{\mathrm{S}}$ isolates (19). In the present study, $\operatorname{Bos}^{\mathrm{R}}$ isolates were further classified into various resistance phenotypes based on the $\mathrm{EC}_{50}$ values of boscalid for them: low resistance to boscalid if the resistance factor (RF) (folds of $\mathrm{EC}_{50}$ value of boscalid for a resistant isolate relative to the mean $\mathrm{EC}_{50}$ value of boscalid [= $\left.0.631 \mu \mathrm{g} / \mathrm{ml}\right]$ for the baseline sensitive isolates $)<10$, moderate resistance if $10 \leq \mathrm{RF}<100$, high resistance if $100 \leq \mathrm{RF}<1,000$, and very high resistance if $\mathrm{RF} \geq 1,000$.

Cross-resistance analysis between boscalid and carboxin. In all, $13 \mathrm{Bos}^{\mathrm{R}}$ isolates representing different levels of boscalid resistance and $6 \mathrm{Bos}^{\mathrm{S}}$ isolates were examined for cross-resistance between boscalid and carboxin (Table 3). A formulated carboxin (Vitavax, 34\% a.i.) (Bayer CropScience, Research Triangle Park, NC) was dissolved in sterile distilled water to provide a stock solution at a concentration of $20 \mu \mathrm{g} / \mathrm{ml}$. Carboxin stock solution was added into $2 \%$ WA to produce the following concentrations:

TABLE 1. Boscalid resistance in Botrytis cinerea isolates obtained from the stem and floral parts of symptomless 'Gala' apple fruit in commercial orchards

\begin{tabular}{|c|c|c|c|c|c|}
\hline \multirow[b]{2}{*}{ Orchard $^{\mathrm{a}}$} & \multirow[b]{2}{*}{ Number of isolates } & \multirow[b]{2}{*}{ Number of Bos $^{\mathrm{R}}$ isolates ${ }^{\mathrm{b}}$} & \multicolumn{3}{|c|}{ Number of isolates carrying mutation in the $B c S d h B$ gene $^{c}$} \\
\hline & & & $\mathrm{H} 272 \mathrm{Y}$ & $\mathrm{H} 272 \mathrm{R}$ & $\mathrm{P} 225 \mathrm{~F}$ \\
\hline $\mathrm{C} 1$ & 51 & 19 & 1 & 17 & 1 \\
\hline $\mathrm{C} 2$ & 45 & 9 & 4 & 5 & 0 \\
\hline $\mathrm{C} 3$ & 24 & 3 & 1 & 2 & 0 \\
\hline $\mathrm{C} 4$ & 47 & 5 & 2 & 3 & 0 \\
\hline $\mathrm{C} 5$ & 53 & 6 & 3 & 3 & 0 \\
\hline Total & 220 & 42 & 11 & 30 & 1 \\
\hline
\end{tabular}

a Pyraclostrobin + boscalid (Pristine) had been used in each of the four consecutive years in these orchards since 2005.

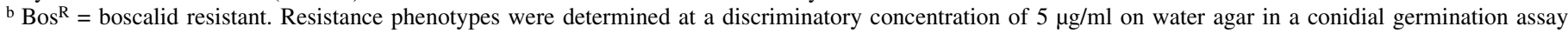
(19). Conidial germination of sensitive isolates was completely inhibited at the discriminatory concentration, whereas resistant isolates were able to germinate. c $\mathrm{H} 272 \mathrm{Y}$ and $\mathrm{H} 272 \mathrm{R}=$ the amino acid His replaced respectively by Tyr and Arg at codon 272; P225F = Pro substituted by Phe at codon 225 . 
TABLE 2. Characteristics of boscalid-resistant isolates of Botrytis cinerea from apple

\begin{tabular}{|c|c|c|c|c|c|c|c|}
\hline Isolate & Year of isolation & Orchard $^{\mathrm{a}}$ & Type of sample ${ }^{b}$ & $\mathrm{EC}_{50}$ of boscalid & Phenotype $^{c}$ & Mutation in $B c S d h B$ & Type of mutant ${ }^{\mathrm{d}}$ \\
\hline 6632 & 2007 & $\mathrm{O} 1$ & A & 8.82 & MR & $\mathrm{H} 272 \mathrm{R}$ & II \\
\hline 7420 & 2009 & $\mathrm{O} 1$ & A & 86.608 & HR & $\mathrm{H} 272 \mathrm{R}$ & II \\
\hline 7434 & 2009 & $\mathrm{O} 1$ & A & 251.74 & HR & $\mathrm{H} 272 \mathrm{R}$ & II \\
\hline 7437 & 2009 & $\mathrm{O} 1$ & A & 17.441 & MR & $\mathrm{H} 272 \mathrm{Y}$ & I \\
\hline 7391 & 2008 & $\mathrm{C} 8$ & A & 490.25 & HR & $\mathrm{H} 272 \mathrm{Y}$ & I \\
\hline 7392 & 2008 & $\mathrm{C} 8$ & A & 17.517 & MR & $\mathrm{H} 272 \mathrm{R}$ & II \\
\hline 7451 & 2009 & $\mathrm{C} 4$ & A & 12.122 & MR & $\mathrm{H} 272 \mathrm{R}$ & II \\
\hline 7465 & 2009 & $\mathrm{C} 5$ & A & $>631$ & VHR & $\mathrm{H} 272 \mathrm{Y}$ & I \\
\hline 7466 & 2009 & C5 & A & $>631$ & VHR & $\mathrm{H} 272 \mathrm{Y}$ & I \\
\hline 7474 & 2009 & $\mathrm{C} 3$ & A & 6.385 & MR & H272R & II \\
\hline 7477 & 2009 & $\mathrm{C} 3$ & A & 6.421 & MR & $\mathrm{H} 272 \mathrm{R}$ & II \\
\hline 7491 & 2009 & $\mathrm{C} 3$ & A & $>631$ & VHR & $\mathrm{H} 272 \mathrm{R}$ & II \\
\hline 7494 & 2009 & $\mathrm{C} 2$ & A & 7.197 & MR & $\mathrm{H} 272 \mathrm{R}$ & II \\
\hline 7626 & 2009 & C7 & A & 5.850 & LR & $\mathrm{H} 272 \mathrm{Y}$ & I \\
\hline 7647 & 2009 & $\mathrm{C} 7$ & A & 6.122 & LR & $\mathrm{H} 272 \mathrm{Y}$ & I \\
\hline 7679 & 2009 & C6 & A & 5.799 & LR & $\mathrm{H} 272 \mathrm{R}$ & II \\
\hline 7936 & 2009 & $\mathrm{C} 2$ & B & 8.759 & MR & $\mathrm{H} 272 \mathrm{R}$ & II \\
\hline 7999 & 2009 & $\mathrm{C} 2$ & B & 4.473 & LR & $\mathrm{H} 272 \mathrm{Y}$ & I \\
\hline 8000 & 2009 & $\mathrm{C} 2$ & B & 214.989 & HR & $\mathrm{H} 272 \mathrm{R}$ & II \\
\hline 8001 & 2009 & $\mathrm{C} 2$ & B & $>631$ & VHR & $\mathrm{H} 272 \mathrm{Y}$ & I \\
\hline 8002 & 2009 & $\mathrm{C} 2$ & B & 159.583 & HR & $\mathrm{H} 272 \mathrm{Y}$ & I \\
\hline 8003 & 2009 & $\mathrm{C} 2$ & B & 10.155 & MR & $\mathrm{H} 272 \mathrm{R}$ & II \\
\hline 8016 & 2009 & $\mathrm{C} 2$ & B & 9.288 & MR & $\mathrm{H} 272 \mathrm{Y}$ & I \\
\hline 8018 & 2009 & $\mathrm{C} 2$ & B & 17.057 & MR & $\mathrm{H} 272 \mathrm{R}$ & II \\
\hline 8019 & 2009 & $\mathrm{C} 2$ & B & 12.117 & MR & H272R & II \\
\hline 8022 & 2009 & $\mathrm{C} 5$ & B & 73.698 & HR & $\mathrm{H} 272 \mathrm{R}$ & II \\
\hline 8036 & 2009 & $\mathrm{C} 5$ & B & $>631$ & VHR & $\mathrm{H} 272 \mathrm{Y}$ & I \\
\hline 8193 & 2009 & $\mathrm{C} 1$ & $\mathrm{~B}$ & 11.485 & MR & $\mathrm{H} 272 \mathrm{R}$ & II \\
\hline 8195 & 2009 & $\mathrm{C} 1$ & B & 4.732 & LR & $\mathrm{H} 272 \mathrm{R}$ & II \\
\hline 8196 & 2009 & $\mathrm{C} 1$ & B & 8.032 & MR & $\mathrm{H} 272 \mathrm{R}$ & II \\
\hline 8198 & 2009 & $\mathrm{C} 1$ & B & 12.156 & MR & $\mathrm{H} 272 \mathrm{R}$ & II \\
\hline 8200 & 2009 & $\mathrm{C} 1$ & $\mathrm{~B}$ & $>631$ & VHR & $\mathrm{H} 272 \mathrm{R}$ & II \\
\hline 8201 & 2009 & $\mathrm{C} 1$ & B & 4.445 & LR & $\mathrm{H} 272 \mathrm{R}$ & II \\
\hline 8204 & 2009 & $\mathrm{C} 1$ & B & 8.848 & MR & H272R & II \\
\hline 8208 & 2009 & $\mathrm{C} 1$ & B & 108.836 & HR & $\mathrm{H} 272 \mathrm{R}$ & II \\
\hline 8209 & 2009 & $\mathrm{C} 1$ & B & $>631$ & VHR & $\mathrm{H} 272 \mathrm{R}$ & II \\
\hline 8211 & 2009 & $\mathrm{C} 1$ & B & 6.162 & LR & $\mathrm{H} 272 \mathrm{R}$ & II \\
\hline 8218 & 2009 & $\mathrm{C} 1$ & B & 8.094 & MR & $\mathrm{H} 272 \mathrm{R}$ & II \\
\hline 8219 & 2009 & $\mathrm{C} 1$ & B & 6.469 & MR & $\mathrm{H} 272 \mathrm{R}$ & II \\
\hline 8220 & 2009 & $\mathrm{C} 1$ & B & $>631$ & VHR & $\mathrm{P} 225 \mathrm{~F}$ & III \\
\hline 8222 & 2009 & $\mathrm{C} 1$ & B & 7.474 & MR & H272R & II \\
\hline 8223 & 2009 & $\mathrm{C} 1$ & $\mathrm{~B}$ & 6.215 & LR & $\mathrm{H} 272 \mathrm{R}$ & II \\
\hline 8230 & 2009 & $\mathrm{C} 1$ & B & 6.294 & LR & $\mathrm{H} 272 \mathrm{R}$ & II \\
\hline 8232 & 2009 & $\mathrm{C} 1$ & B & 9.221 & MR & $\mathrm{H} 272 \mathrm{Y}$ & I \\
\hline 8234 & 2009 & $\mathrm{C} 1$ & B & 7.235 & MR & $\mathrm{H} 272 \mathrm{R}$ & II \\
\hline 8255 & 2009 & $\mathrm{C} 5$ & $\mathrm{~B}$ & $>631$ & VHR & $\mathrm{H} 272 \mathrm{Y}$ & I \\
\hline 8300 & 2009 & C5 & B & $>631$ & VHR & $\mathrm{H} 272 \mathrm{R}$ & II \\
\hline 8301 & 2009 & C5 & B & 16.137 & MR & $\mathrm{H} 272 \mathrm{R}$ & II \\
\hline
\end{tabular}

${ }^{a}$ In conventional orchards (C1 to C8), Pristine (pyraclostrobin + boscalid) had been used in each of the four consecutive seasons since 2005, whereas no synthetic fungicides were used in the organic orchard (O1) since the mid-1990s.

${ }^{\mathrm{b}} \mathrm{A}=$ decayed fruit sampled from fruit packinghouses and $\mathrm{B}=$ stems and floral parts of symptomless fruit sampled from apple orchards before harvest.

${ }^{\mathrm{c}} \mathrm{LR}=$ low resistance to boscalid (resistance factor $\left.[\mathrm{RF}]<10\right), \mathrm{MR}=$ moderate resistance to boscalid $(10 \leq \mathrm{RF}<100)$, $\mathrm{HR}=$ high resistance to boscalid $(100 \leq \mathrm{RF}$ $<1,000)$, and VHR = very high resistance to boscalid $(\mathrm{RF} \geq 1,000)$.

d I, II, and III = boscalid-resistant mutants carrying H272Y, H272R, and P225F mutations, respectively, in the BcSdhB gene. 
$0,0.1,0.5,1,2.5,5,7.5,10$, and $20 \mu \mathrm{g} / \mathrm{ml}$ for $\operatorname{Bos}^{\mathrm{R}}$ isolates and 0 , $0.01,0.05,0.1,0.25,0.5$, and $0.75 \mu \mathrm{g} / \mathrm{ml}$ for Bos ${ }^{\mathrm{S}}$ isolates. $\mathrm{EC}_{50}$ values for conidial germination were determined as described above. The experiment was performed twice.

Correlation analysis was performed using PROC CORR of SAS $(P=0.05)$ to determine whether there was cross resistance between boscalid and carboxin for 14 isolates tested. The logtransformed $\mathrm{EC}_{50}$ values of both fungicides were used for analysis. The five very highly $\operatorname{Bos}^{\mathrm{R}}$ isolates were not included in the analysis because no definitive $\mathrm{EC}_{50}$ values of boscalid $(>631 \mu \mathrm{g} / \mathrm{ml})$ were available for these isolates. However, a $t$ test using SAS PROC TTEST $(P=0.05)$ was performed with all isolates listed in Table 3 to determine whether $\mathrm{EC}_{50}$ values of carboxin for $\mathrm{Bos}^{\mathrm{R}}$ isolates were significantly higher than those for $\mathrm{Bos}^{\mathrm{S}}$ isolates.

Analysis of DNA sequence of the $B c S d h B$ gene from $B_{0 s}{ }^{R}$ and Bos ${ }^{\mathrm{S}}$ isolates. Genomic DNA was extracted from mycelium of $B$. cinerea using the FastDNA kit and the FastPrep instrument (MP Biomedicals, Irvine, CA) according to the manufacturer's

TABLE 3. Sensitivity of conidial germination to carboxin in boscalid-sensitive and -resistant isolates of Botrytis cinerea from apple

\begin{tabular}{llccc}
\hline & & & \multicolumn{2}{c}{$\mathrm{EC}_{50}(\mu \mathrm{g} / \mathrm{ml})^{\mathrm{c}}$} \\
\cline { 4 - 5 } Isolate & Phenotype $^{\mathrm{a}}$ & Genotype $^{\mathrm{b}}$ & Boscalid & Carboxin \\
\hline 1927 & $\mathrm{~S}$ & Wild & 0.919 & 0.120 \\
1922 & $\mathrm{~S}$ & Wild & 1.476 & 0.145 \\
1940 & $\mathrm{~S}$ & Wild & 0.586 & 0.125 \\
1859 & $\mathrm{~S}$ & Wild & 0.667 & 0.104 \\
6631 & $\mathrm{~S}$ & Wild & 0.341 & 0.055 \\
6705 & $\mathrm{~S}$ & Wild & 0.911 & 0.070 \\
Mean & $\ldots$ & $\ldots$ & 0.817 & 0.103 \\
7999 & LR & I & 4.473 & 0.459 \\
8133 & LR & I & 5.580 & 1.750 \\
7638 & MR & I & 17.441 & 3.340 \\
8184 & VHR & I & $>631$ & 2.350 \\
8080 & VHR & I & $>631$ & 1.683 \\
7640 & VHR & I & $>631$ & 1.563 \\
8201 & LR & II & 4.445 & 0.595 \\
7679 & LR & II & 5.799 & 0.752 \\
8186 & MR & II & 31.462 & 1.011 \\
7420 & HR & II & 86.608 & 1.325 \\
7633 & HR & II & 237.877 & 2.625 \\
8300 & VHR & II & $>631$ & 2.183 \\
8220 & VHR & III & $>631$ & 3.848 \\
Mean & $\ldots$ & $\ldots$ & $>272.976$ & 1.806 \\
\hline
\end{tabular}

a Phenotype of sensitivity to boscalid: $\mathrm{S}=$ sensitive to boscalid, $\mathrm{LR}=$ low resistance to boscalid (resistance factor $[\mathrm{RF}]<10$ ), $\mathrm{MR}=$ moderate resistance to boscalid $(10 \leq \mathrm{RF}<100)$, HR $=$ high resistance to boscalid $(100 \leq \mathrm{RF}<1,000), \mathrm{VHR}=$ very high resistance to boscalid $(\mathrm{RF} \geq 1,000)$.

${ }^{b}$ Wild = wild type, $\mathrm{I}=$ boscalid-resistant mutants carrying mutation $\mathrm{H} 272 \mathrm{Y}$ in the $B c S d h B$ gene, II = boscalid-resistant mutants carrying mutation $\mathrm{H} 272 \mathrm{R}$ in the $B c S d h B$ gene, and III = boscalid-resistant mutants carrying mutation $\mathrm{P} 225 \mathrm{~F}$ in the $B c S d h B$ gene.

${ }^{\mathrm{c}} \mathrm{EC}_{50}$ values $=$ the concentration of boscalid that inhibits fungal growth by $50 \%$ relative to control for the six boscalid-sensitive isolates originated from the previous study reported by Kim and Xiao (19). instructions. Based on the sequence of the $S d h B$ gene in $B$. cinerea $(B c S d h B)($ GenBank accession number AY726618.1), the primer pair SdhB-F + SdhB-R (Table 4) was designed to amplify a fragment containing the codons 225 and 272 in the $B c S d h B$ gene from $13 \mathrm{Bos}^{\mathrm{R}}$ and $9 \mathrm{Bos}^{\mathrm{S}}$ isolates. PCR amplifications were performed in a $25-\mu \mathrm{l}$ volume containing $20 \mathrm{ng}$ of fungal genomic DNA, $0.2 \mu \mathrm{M}$ each primer, $0.2 \mathrm{mM}$ each of dNTP (Promega Corp., Madison, WI), $1.5 \mathrm{mM} \mathrm{MgCl}_{2}, 1 \times$ Promega Taq polymerase buffer (10 mM Tris- $\mathrm{HCl}, \mathrm{pH} 9.0 ; 50 \mathrm{mM} \mathrm{KCl}$; and $0.1 \%$ Triton X-100), and 1.5 units of Taq polymerase (Promega Corp.). PCR was carried out in an iCycler thermal cycler (Bio-Rad Life Science Research Group, Hercules, CA) with the following parameters: an initial preheating for $3 \mathrm{~min}$ at $95^{\circ} \mathrm{C}$; followed by 35 cycles of denaturation at $94^{\circ} \mathrm{C}$ for $40 \mathrm{~s}$, annealing at $56^{\circ} \mathrm{C}$ for $40 \mathrm{~s}$, and extension at $72^{\circ} \mathrm{C}$ for $1 \mathrm{~min}$; and a final extension at $72^{\circ} \mathrm{C}$ for $5 \mathrm{~min}$. The PCR products were separated on $1.5 \%$ agarose gels in $1 \times$ Tris-acetate-EDTA (TAE) buffer and photographed after staining with ethidium bromide.

Using this pair of primers, a 675-bp single PCR fragment was amplified from each tested isolate. PCR products were purified using the QIAquick PCR purification kit (Qiagen Inc., Valencia, CA) according to the manufacturer's instructions. Cycle sequencing was performed using the ABI Prism BigDye Terminator v3.1 Cycle Sequencing kit (Applied Biosystems, Foster City, CA) and PCR primers. The sequencing reaction mixture contained 0.5 to $1 \mu \mathrm{g}$ of DNA, $3.2 \mathrm{pmol}$ primer, $4 \mu \mathrm{l}$ of BigDye Terminator Cycle Sequencing Ready Reaction Mix, and sterile distilled water in $10-\mu$ total volumes. Cycle sequencing was carried out at $96^{\circ} \mathrm{C}$ for $15 \mathrm{~s}, 50^{\circ} \mathrm{C}$ for $15 \mathrm{~s}$, and $60^{\circ} \mathrm{C}$ for $4 \mathrm{~min}$ for 25 cycles. Products were purified using Centriflex Gel Filtration Cartridges (Edge Biosystems, Gaithersburg, MD) and dried in a speed vacuum concentrator. Sequences were read in the Laboratory for Biotechnology and Bioanalysis, School of Molecular Biosciences, Washington State University, Pullman. Representative sequences were deposited in GenBank under accession numbers HQ622627 to HQ622630.

Development of allele-specific PCR assays for detection of mutations at the codon position 272 in the $B c S d h B$ gene. Two types of point mutations at the codon position $272(\mathrm{H} 272 \mathrm{Y} / \mathrm{R})$ in $B c S d h B$ were observed in $\mathrm{Bos}^{\mathrm{R}}$ isolates sequenced, and we then designed three pairs of allele-specific primers for detection of these point mutations (Table 4). Based on one point mutation from $\mathrm{C}$ (CAC in Bos ${ }^{\mathrm{S}}$ isolates) to $\mathrm{T}$ (TAC in $\mathrm{Bos}^{\mathrm{R}}$ isolates) at the codon position 272, a nucleotide $\mathrm{A}$ at the $3^{\prime}$ end of the reverse primer 272Y-R was designed to match the $\mathrm{T}$ at this codon position in $\mathrm{Bos}^{\mathrm{R}}$ isolates. Similarly, based on the other point mutation from A to $\mathrm{G}$ (CGC in $\mathrm{Bos}^{\mathrm{R}}$ isolates) at the codon position 272, a nucleotide $\mathrm{G}$ at the $3^{\prime}$ end of the forward primer $272 \mathrm{R}-\mathrm{F} 2$ and a nucleotide $\mathrm{C}$ at the $3^{\prime}$ end of the reverse primer $272 \mathrm{R}-\mathrm{R}$ were designed to match the $\mathrm{G}$ at this codon position in $\operatorname{Bos}^{\mathrm{R}}$ isolates. Previous studies have shown that the addition of an extra mismatch base, together with the natural mutation base at the $3^{\prime}$ end of primer, can increase the specificity of the primers in

TABLE 4. Polymerase chain reaction (PCR) primers used in this study

\begin{tabular}{lll}
\hline Primer & \multicolumn{1}{c}{ Sequence $\left(5^{\prime}-3^{\prime}\right)$} & \multicolumn{1}{c}{ Relevant characteristics $^{\mathrm{a}}$} \\
\hline SdhB-F & AAGGTATCTGCGGCAGTTGTG & PCR primers for amplification of partial SdhB gene containing codons 225 and 272 in Botrytis cinerea \\
SdhB-R & TAGCAATAACCGCCCAAAAC & $\ldots$ \\
272Y/R-F & AAGGAGGATCGTAAGAAGCTTG & Allele-specific PCR primers for the detection of Bos ${ }^{\mathrm{R}}$ isolates of B. cinerea carrying the H272Y mutation \\
272Y-R & TCGAGCAGTTGAGAATAGTGTA & $\ldots$ \\
272Y/R-F & AAGGAGGATCGTAAGAAGCTTG & Allele-specific PCR primers for the detection of Bos ${ }^{\mathrm{R}}$ isolates of B. cinerea carrying the H272R mutation \\
272R-R & TCGAGCAGTTGAGAATAGTGC & $\ldots$ \\
272R-F2 & GCATGAGTTTGTACAGATGTAG & $\ldots$ \\
272R-R2 & TTAGCAATAACCGCCCAAAAC & $\ldots$ \\
$(\text { AAC })_{5}$ & AACAACAACAACAAC & Microsatellite primers for analysis of genetic variation in populations of $B$. cinerea \\
$(\mathrm{GACA})_{4}$ & GACAGACAGACAGACA & $\ldots$ \\
$\mathrm{M} 13$ & GAGGGTGGCGGTTCT & $\ldots$ \\
\hline
\end{tabular}

${ }^{\mathrm{a}} \mathrm{Bos}^{\mathrm{R}}=$ boscalid resistant. 
detecting point mutations $(9,32)$. To improve the specificity of traditional allele-specific PCR amplifications, we introduced an artificial mismatch base A at the second nucleotide at the $3^{\prime}$ end of primer 272R-F2 (Table 4). Primers 272Y/R-F and 272R-R2 were designed based on the sequence AY726618.1 in GenBank. PCR amplification parameters were an initial preheating for $3 \mathrm{~min}$ at $95^{\circ} \mathrm{C} ; 35$ cycles of denaturation at $94^{\circ} \mathrm{C}$ for $30 \mathrm{~s}$, annealing at $62^{\circ} \mathrm{C}(272 \mathrm{Y} / \mathrm{R}-\mathrm{F}+272 \mathrm{Y}-\mathrm{R}$ or $272 \mathrm{R}-\mathrm{R}), 59^{\circ} \mathrm{C}(272 \mathrm{R}-\mathrm{F} 2+272 \mathrm{R}-$ $\mathrm{R} 2$ ) for $30 \mathrm{~s}$, and extension at $72^{\circ} \mathrm{C}$ for $30 \mathrm{~s}$; and terminated with a final extension at $72^{\circ} \mathrm{C}$ for $5 \mathrm{~min}$.

All $66 \mathrm{Bos}^{\mathrm{R}}$ and $106 \mathrm{Bos}^{\mathrm{S}}$ isolates were tested for the specificity of three allele-specific PCR assays described above. Amplifying with the three pairs of primers $(272 \mathrm{Y} / \mathrm{R}-\mathrm{F}+272 \mathrm{Y}-\mathrm{R}$, 272Y/R-F + 272R-R, and 272R-F2 + 272R-R2) (Table 4), 65 $\mathrm{Bos}^{\mathrm{R}}$ isolates gave positive amplifications, and $106 \mathrm{Bos}^{\mathrm{S}}$ isolates and 1 Bos $^{\mathrm{R}}$ isolate 8022 produced no PCR amplifications. DNA sequencing was further performed for isolate 8022 to detect whether other point mutations occurred in the $B c S d h B$ gene with primer pair SdhB-F + SdhB-R.

For the simultaneous detection of both mutations at the codon position 272 in $B c S d h B$, three primers (272Y/R-F, 272Y-R, and 272R-R) were used in single-PCR amplifications. PCR conditions used for the multiplex PCR assay were the same as described above.

Genetic relationships between the $\operatorname{Bos}^{\mathrm{R}}$ and $\operatorname{Bos}^{\mathrm{S}}$ isolates. To investigate genetic relationships between the $\operatorname{Bos}^{\mathrm{R}}$ and $\mathrm{Bos}^{\mathrm{S}}$ isolates, $39 \mathrm{Bos}^{\mathrm{R}}$ and $56 \mathrm{Bos}^{\mathrm{S}}$ isolates were analyzed by microsatellite-primed PCR (MP-PCR) with three microsatellite primers: $(\mathrm{AAC})_{5},(\mathrm{GACA})_{4}$, and M13 (Table 4). These three primers were chosen because they were informative in determining genetic relationships among $B$. cinerea isolates (24). PCR was conducted with an initial preheat at $95^{\circ} \mathrm{C}$ for $3 \mathrm{~min}$; followed by 40 cycles of denaturation at $94^{\circ} \mathrm{C}$ for $1 \mathrm{~min}$, annealing at $45^{\circ} \mathrm{C}$ for $1 \mathrm{~min}$, and extension at $72^{\circ} \mathrm{C}$ for $1.5 \mathrm{~min}$; and terminated with a final extension at $72^{\circ} \mathrm{C}$ for $7 \mathrm{~min}$. Each isolate was amplified twice. The PCR products were separated on $1.2 \%$ agarose gels in $1 \times$ TAE buffer and photographed after staining with ethidium bromide.

To analyze MP-PCR data, each isolate was scored for the presence or absence of each amplicon using UVP GelDoc-It Imaging System (Ultra Violet Products, Upland, CA). Genetic similarities (S) were calculated using simple matching coefficient. A phenogram was constructed using the unweighted pairgroup method with arithmetic average (UPGMA) by the program Sequential, Agglomerative, Hierarchical, and Nested clustering methods of the software package NTSYS-pc 2.1 (Department of Ecology and Evolution, State University of New York).

\section{RESULTS}

Boscalid resistance in apple orchards. Of the 220 isolates obtained from Gala apple fruit in five orchards where the boscalid-containing fungicide Pristine had been used for at least four consecutive years, 42 isolates $(19.1 \%)$ were resistant to boscalid (Table 1). The frequency of $\operatorname{Bos}^{\mathrm{R}}$ isolates was 11 to $37 \%$ among the orchards sampled.

Phenotypes of boscalid resistance. $\mathrm{EC}_{50}$ values of the $42 \mathrm{Bos}^{\mathrm{R}}$ isolates obtained from apple fruit in orchards and 24 additional $\operatorname{Bos}^{\mathrm{R}}$ isolates obtained from decayed apple fruit collected from commercial fruit packinghouses ranged from 4.445 to $>631 \mu \mathrm{g} / \mathrm{ml}$ and from 5.799 to $>631 \mu \mathrm{g} / \mathrm{ml}$, respectively (Table 2). Of the 66 $\operatorname{Bos}^{\mathrm{R}}$ isolates, 10 were low resistant to boscalid, with $\mathrm{EC}_{50}$ values of 4.445 to $6.294 \mu \mathrm{g} / \mathrm{ml}(\mathrm{RF}<10) ; 31$ were moderately resistant, with $\mathrm{EC}_{50}$ values of 6.385 to $31.462 \mu \mathrm{g} / \mathrm{ml}(10<\mathrm{RF}<100) ; 12$ were highly resistant, with $\mathrm{EC}_{50}$ values of 63.35 to $490.25 \mu \mathrm{g} / \mathrm{ml}$ $(100<\mathrm{RF}<1,000)$; and 13 were very highly resistant, with $\mathrm{EC}_{50}$ values $>631 \mu \mathrm{g} / \mathrm{ml}(\mathrm{RF}>1,000)$ (Table 2$)$.

Cross-resistance between boscalid and carboxin in $B$. cinerea. The $\mathrm{EC}_{50}$ values of carboxin for $13 \mathrm{Bos}^{\mathrm{R}}$ and $6 \mathrm{Bos}^{\mathrm{S}}$ isolates are shown in Table 3. Pearson correlation analysis indicated that $\mathrm{EC}_{50}$ values between boscalid and carboxin were highly correlated $(r=0.8853, P<0.0001, n=14)$. The $t$ test also showed that the mean $\mathrm{EC}_{50}$ values of carboxin for $\mathrm{Bos}^{\mathrm{R}}$ isolates were significantly higher than those for Bos ${ }^{\mathrm{S}}$ isolates $(P<0.0001$, $n=19$ ), indicating a high level of cross-resistance between boscalid and carboxin.

Sequence comparison of the $B c S d h B$ gene between $\operatorname{Bos}^{\mathrm{R}}$ and $\mathrm{Bos}^{\text {S }}$ isolates. The partial nucleotide sequences of $B c S d h B$ were compared for $13 \operatorname{Bos}^{\mathrm{R}}$ isolates $(6632,7420,7434,7436$, 7437, 7391, 7392, 7451, 7453, 7455, 7465, 7466, and 7494) and 9 Bos ${ }^{\text {s }}$ isolates $(288,1753,1760,1924,6627,6628,6635,7435$, and 7452). Analysis of the DNA sequence of $B c S d h B$ showed that the codon $\mathrm{CAC}$ for His at the position 272 was replaced by the codon TAC for Tyr in four Bos ${ }^{\mathrm{R}}$ isolates (H272Y), and by CGC for Arg in nine Bos ${ }^{\mathrm{R}}$ isolates (H272R) (Fig. 1). Except for the two point mutations at position 272 in Bos $^{\mathrm{R}}$ isolates, all 22 isolates analyzed had identical deduced amino acid sequences in the $B c S d h B$ gene.

Molecular diagnosis of $\operatorname{Bos}^{\mathrm{R}}$ isolates mutated in the $\mathrm{BcSdhB}$ gene. The expected 232-bp fragment was amplified from $B_{o s}{ }^{R}$ isolates carrying mutations $\mathrm{H} 272 \mathrm{Y}$ or $\mathrm{H} 272 \mathrm{R}$ in the $B c S d h B$ gene using the primer pairs $272 \mathrm{Y} / \mathrm{R}-\mathrm{F}+272 \mathrm{Y}-\mathrm{R}$ and $272 \mathrm{Y} / \mathrm{R}-\mathrm{F}+$ 272R-R, respectively. No amplifications were observed from the $106 \mathrm{Bos}^{\mathrm{S}}$ isolates tested and $1 \mathrm{Bos}^{\mathrm{R}}$ isolate carrying mutations other than $\mathrm{H} 272 \mathrm{Y} / \mathrm{R}$ in the $B c S d h B$ gene (Fig. 2A and B). Using prime pair 272R-F2 + 272R-R2, the expected 197-bp fragment was amplified only from $\mathrm{Bos}^{\mathrm{R}}$ isolates carrying the mutation $\mathrm{H} 272 \mathrm{R}$ (data not shown). Of the 42 field $\operatorname{Bos}^{\mathrm{R}}$ isolates from five orchards, 11 had the mutation $\mathrm{H} 272 \mathrm{Y}$ (designated as type I mutant) and 30 carried the mutation H272R (designated as type II mutant) (Tables 1 and 2), indicating that type I and II mutants were the major genotypes of $\mathrm{Bos}^{\mathrm{R}}$ populations in the field. Among the total $66 \mathrm{Bos}^{\mathrm{R}}$ isolates tested (including $24 \mathrm{Bos}^{\mathrm{R}}$ isolates obtained from decayed apple fruit), 19 belonged to the type I mutant and 46 belonged to the type II mutant (Table 2). Analyzing the sequence of the $B c S d h B$ gene for isolate 8220 that gave no amplifications with the three pairs of primers described above (Fig. 2A and B), a new point mutation (P225F) was detected. The codon $\mathrm{CCC}$ for Pro $(\mathrm{P})$ at position 225 present in the Bos $^{\mathrm{S}}$ isolates was changed to the TTC for Phe $(\mathrm{F})$ in isolate 8220 . The mutation P225F was designated as a type III mutant (Fig. 1; Table 2).

To simultaneously detect both mutations at codon 272 in single-PCR amplifications, a multiplex PCR assay was developed. Analysis of $66 \mathrm{Bos}^{\mathrm{R}}$ and $106 \mathrm{Bos}^{\mathrm{S}}$ isolates with the multiplex PCR assay showed that a 232-bp fragment was amplified from each of the $65 \mathrm{Bos}^{\mathrm{R}}$ isolates carrying either the H272Y or H272R mutation, and that no PCR amplifications were obtained from the type III mutant containing mutation $\mathrm{P} 225 \mathrm{~F}$ and all $\mathrm{Bos}^{\mathrm{S}}$ isolates (Fig. 2C).

Levels of boscalid resistance within $\operatorname{Bos}^{\mathrm{R}}$ isolates carrying either the H272R or H272Y mutation. Of the 19 type I mutants carrying the H272Y mutation, $4(21.1 \%)$ exhibited a low level of resistance to boscalid, with $\mathrm{RF}<10 ; 5(26.3 \%)$ were moderately resistant, with RF of 10 to $100 ; 2$ (10.5\%) were highly resistant, with RF of 100 to 1,000 ; and $8(42.1 \%)$ were very highly resistant, with $\mathrm{RF}>1,000$ (Fig. 3). Of the 46 type II mutants containing the H272R mutation, 6 (13.0\%) showed low resistance to boscalid, $26(56.5 \%)$ were moderately resistant, $10(21.7 \%)$ were highly resistant, and $4(8.7 \%)$ were very highly resistant (Fig. 3). The results indicated that all four $\operatorname{Bos}^{\mathrm{R}}$ phenotypes were present in both type I and type II mutants and that different Bos $^{R}$ phenotypes were not associated with particular types of mutations at codon position 272 among Bos $^{\mathrm{R}}$ isolates.

Genetic relationships between $\operatorname{Bos}^{\mathrm{R}}$ (type I and II mutants) and $\operatorname{Bos}^{S} B$. cinerea isolates. Three microsatellite primers generated a total of 27 polymorphic fragments and 46 haplotypes 
from $39 \operatorname{Bos}^{\mathrm{R}}$ (19 type I, 19 type II, and 1 type III mutants) and $56 \mathrm{Bos}^{\mathrm{S}}$ isolates. Examples of DNA fingerprint patterns generated by the primer $(\mathrm{AAC})_{5}$ are presented in Figure 4. The UPGMA analysis showed that $97.9 \%$ isolates were clustered into groups A (41.1\%), B (31.6\%), and C (25.3\%) (Fig. 5). In all, $28 \mathrm{Bos}^{\mathrm{R}}(15$ type I, 12 type II, and 1 type III mutants) and $11 \mathrm{Bos}^{\mathrm{S}}$ isolates were clustered into group A. In total, $11 \mathrm{Bos}^{\mathrm{R}}$ (4 type I and 7 type II mutants) and $19 \mathrm{Bos}^{\mathrm{S}}$ isolates were clustered into group $\mathrm{B}$. Group C consisted of $24 \operatorname{Bos}^{\mathrm{S}}$ isolates, and no $\mathrm{Bos}^{\mathrm{R}}$ isolates were clustered into this group (Fig. 5). Additionally, there was no specific association between mutation types and genetic groups based on the MP-PCR analysis among Bos ${ }^{\mathrm{R}}$ mutants.

\section{DISCUSSION}

In the present study, we found a high frequency of Bos ${ }^{\mathrm{R}}$ isolates of $B$. cinerea in apple orchards where the boscalid-containing fungicide Pristine had been used for four consecutive years. Given the fact that Pristine was used only once a year and no other boscalid-containing fungicides were used in these orchards, the results suggest that the risk for development of boscalid resistance in $B$. cinerea is considered high. In a previous related study, boscalid resistance was observed in $B$. cinerea isolates obtained from stored, gray mold-decayed apple fruit sampled from packinghouses, and $\approx 20 \%$ of the isolates were resistant to boscalid (19). In that study, decayed apple fruit originated from the previous season's crops grown in the same orchards whereas, in the present study, $B$. cinerea isolates were collected near harvest before the fungicide Pristine was applied in these apple orchards. Thus, no boscalid-containing fungicides had been applied in these orchards between the two collections. It remains to be determined whether resistance frequency will increase if the boscalid-containing Pristine continues to be used in these orchards.

Numerous studies on the molecular mechanisms conferring SDHI resistance in mutants of various fungi and bacteria have shown that mutations in highly conserved amino acid residues located in subunits $\mathrm{SdhB}$, SdhC, or SdhD in SDH responsible for SDHI resistance $(3,4,7,12,15,16,18,23,26-28)$. It appears that amino acid positions at which mutations occur and types of mutations vary among target pathogens. In many organisms, SDHI resistance is attributed to single-point mutations in the $S d h B$ gene leading to a substitution of a highly conserved histidine residue to tyrosine, arginine, leucine, or asparagine (2). This $\mathrm{His}$ residue, located in a region associated with a [3Fe-4S] highpotential non-heme iron sulfur-redox (S3) center, plays a key role not only in ubiquinone binding and reduction but also in carboxamide (such as carboxin and boscalid) proper binding and thus inhibitory action $(13,14)$. Although Stammler (28) reported that mutations $\mathrm{H} 272 \mathrm{Y} / \mathrm{R}$ and $\mathrm{P} 225 \mathrm{~L} / \mathrm{F} / \mathrm{T}$ correlated with boscalid resistance in $B$. cinerea, no details were given about which mutation type was dominant and whether these mutation types occurred in field-resistant isolates. In the present study, we docu-

\begin{tabular}{|c|c|c|c|}
\hline $88-B S:$ & 221STSq & PYWWNSEEYLGPAILLQSYRWLADSRDQKKEERKAALDNSMSLYRC & FIL \\
\hline$S:$ & & PYWWNSEEYLGPAILLQSYRWLADSRDQKKEERKAALDNSMSL & FILNCSRT \\
\hline BS : & ביב & PYWWNSEEYLGPAILLQSYRWLADSRDQKKEERKAALDNSMSL & FILl \\
\hline BS: & & PYWWNSEEYLGPAILLQSYRWLADSRDQKKEERKAALDNSMSL & \\
\hline DS. & & \$YWWNSEEYLGPAILLQSYRWLADSRDQKKEERKAALDNSMSI & FIL \\
\hline BS : & & PYWWNSEEYLGPAILLQSYRWLADSRDQKKEERKAALDNSMSL & FILNCSRT \\
\hline BS : & & SYV & \\
\hline$-B S:$ & & SYWWNSEEYLGPAILLQSYH & \\
\hline BS: & & PYWWNSEEYLGPAI LLQSYRWLADSRDQKKEERKAALDNSMS & FI \\
\hline $\mathrm{BR}:$ & & PYWWNSEEYLGPAILLQSYRWLADSRDQKKEERKAALDI & ILNCSRTC \\
\hline BR: & & SYV & \\
\hline BR & & & \\
\hline BR: & & SYWWNSEEYLGPAILLQSYRWLADSRDQKK & ILNCSRT \\
\hline R & & SYWWNSEEYLGPAILLQ & II \\
\hline $\mathrm{BR}$ & & SYWWNSEE & \\
\hline $3 \mathrm{R}$ & & PYWWNSEEYLGPAILLQSYRWLADSRDQKKEERKA & IL \\
\hline $\mathrm{BR}$ : & & PYWWNSEEYLGPAILLQSYRWLADSRDQKKEERKAALDNSMS ] & ILNCSRT \\
\hline BR & & SEEYLGPAILI & FI \\
\hline BR & & PYWWNSEEYLGPAILLQSYRWLADSRD & FILN \\
\hline$-B R:$ & & PYWWNSEEYLGPAILLQSYRWLADSRDQKKEERKAALDNSMSLY & FILNCSRTC \\
\hline $5-B R:$ & & PYWWNSEEYLGPAILLQSYRWLADSRDQKKEERKAALDNSMSL & FINCSRTC \\
\hline $6-\mathrm{B}$ & & PYWWNSEEYLGPAILLQ & ILN \\
\hline $0-1$ & & s) & I \\
\hline
\end{tabular}

Fig. 1. Alignment of the deduced amino acid sequences (positions 221 to 281) of the $B c S d h B$ gene from 14 boscalid-resistant (BR) and nine boscalid-sensitive (BS) isolates of Botrytis cinerea. The vertical box indicates the changes at amino acid positions 225 and 272 that were correlated with resistance to boscalid. 
mented that the mutation $\mathrm{H} 272 \mathrm{R}$ was the most frequent genotype in field $\mathrm{Bos}^{\mathrm{R}}$ isolates of $B$. cinerea from apple and that mutation $\mathrm{H} 272 \mathrm{Y}$ also was common in field $\mathrm{Bos}^{\mathrm{R}}$ populations. More recently, H272Y has been reported to be the most frequent genotype in $\operatorname{Bos}^{\mathrm{R}}$ populations of $B$. cinerea in French and German vineyards (22). It appears that the dominance of mutation types in $B c S d h B$ is related to the populations in particular geographic regions and crop species.

Previous studies also indicated that proline at position 225 could be replaced by leucine, phenylalanine, or threonine in lab $\mathrm{Bos}^{\mathrm{R}}$ mutants of $B$. cinerea $(8,22,28)$. However, in our study, only one isolate carried the mutation P225F among the 66 field Bos $^{\mathrm{R}}$ isolates. This indicated that this mutation was not the dominant genotype in field-resistant isolates of B. cinerea from apple. The findings support the conclusion that each mutation found in one particular target-encoding gene can independently result in resistance to SDHIs $(4,22,26)$. Single-point mutations in $S d h C$ and $S d h D$ have also been reported to be correlated with SDHI resistance in some fungal pathogens but these types of mutations are less common compared with those in $\operatorname{SdhB}(2,22)$. In our study, we did not sequence $B c S d h C$ and $B c S d h D$ because point mutations in these two genes are much less common and singlepoint mutations in $B c S d h B$ were detected in all Bos $^{\mathrm{R}}$ isolates, which were consistent with previous reports $(22,28)$. However, it remains to be determined whether frequency of different mutation types in $B c S d h B$ will shift over time or whether mutants carrying different types of mutations in $B c S d h B, B c S d h C$, or $B c S d h D$ will evolve if boscalid or other SDHIs continue to be used in the field.
In the present study, phenotyping of isolates for boscalid resistance and determination of $\mathrm{EC}_{50}$ values of boscalid for resistant isolates were based on a conidial germination assay described previously (19). The results of molecular analysis of point muta-

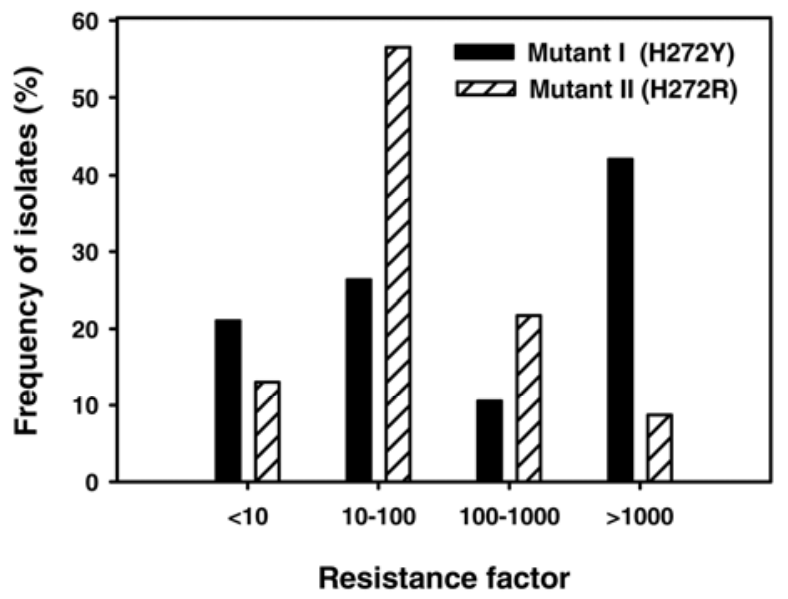

Fig. 3. Frequency distribution of boscalid-resistant isolates of Botrytis cinerea exhibiting different levels of resistance expressed as resistance factor (folds of the concentration of boscalid that inhibits fungal growth by $50 \%$ relative to control $\left[\mathrm{EC}_{50}\right.$ value] for a resistant isolate relative to the mean $\mathrm{EC}_{50}$ value of boscalid for the baseline sensitive isolates) between 19 type I mutants (carrying mutation $\mathrm{H} 272 \mathrm{Y}$ in the $B c S d h B$ gene) and 46 type II mutants (carrying mutation $\mathrm{H} 272 \mathrm{R}$ in the $B c S d h B$ gene).

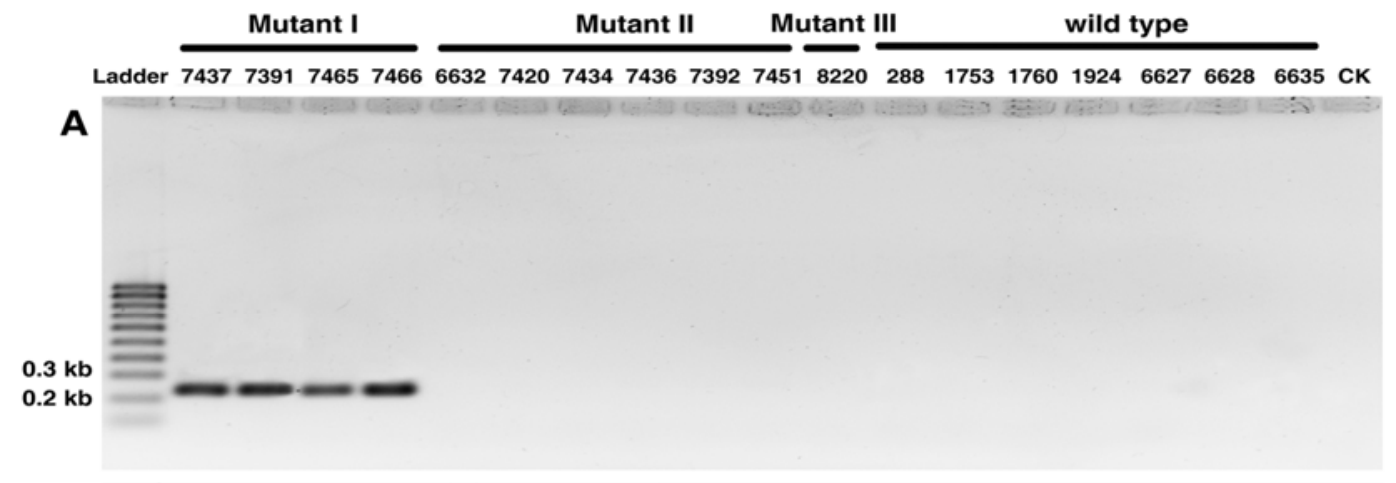

B
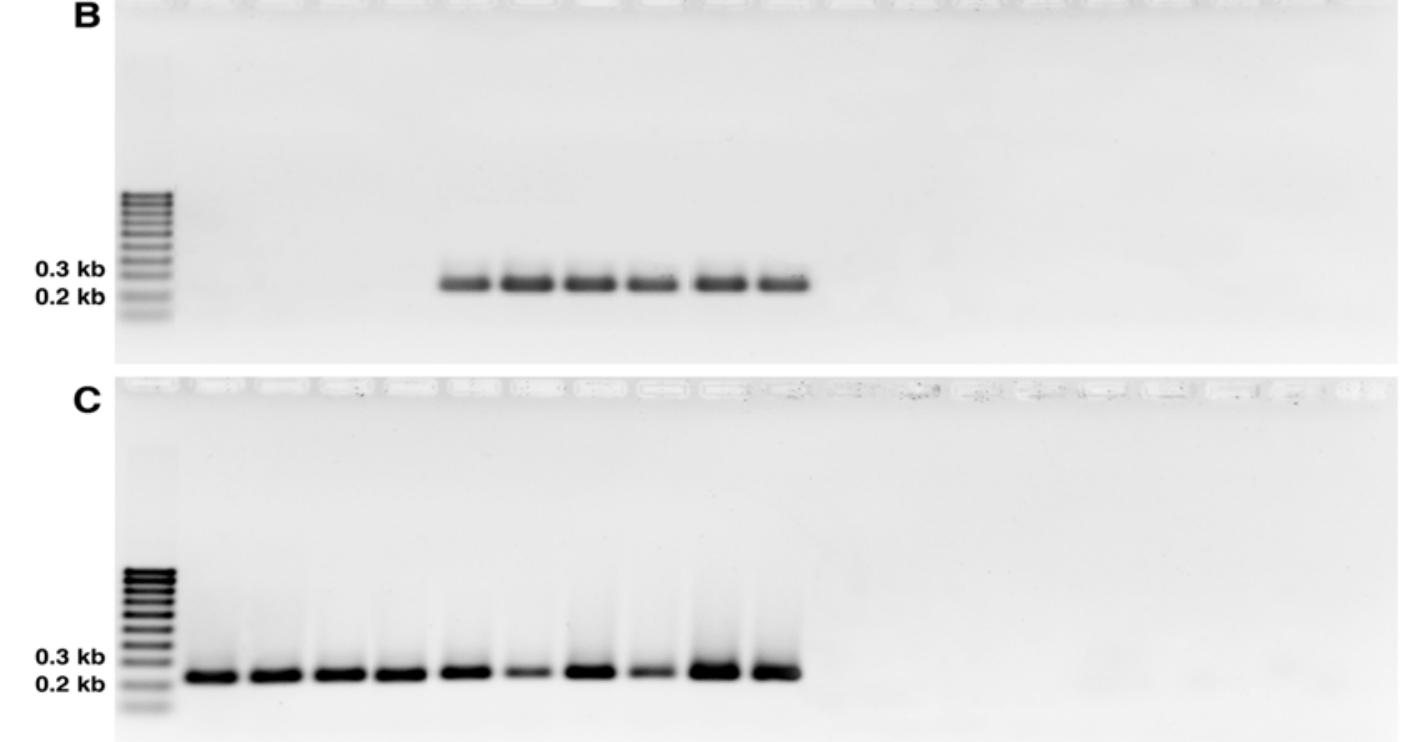

Fig. 2. Specificity of A, the allele-specific polymerase chain reaction (PCR) primer pair 272Y/R-F + 272Y-R; $\mathbf{B}$, the allele-specific PCR primer pair $272 \mathrm{Y} / \mathrm{R}-\mathrm{F}+$ 272R-R; and C, the multiplex allele-specific PCR primers 272Y/R-F + 272Y-R + 272R-R for detection of boscalid-resistant type I mutants (carrying mutation $\mathrm{H} 272 \mathrm{Y}$ in $B c S d h B$ ) and type II mutants (carrying mutation H272R in BcSdhB) of Botrytis cinerea. The first lane ladder is the DNA marker and the last lane CK is a negative control without template DNA. 
tions in $B c S d h B$ were in agreement with those of phenotyping of boscalid resistance based on the conidial germination assay because point mutations in $B c S d h B$ were observed in all Bos $^{\mathrm{R}}$ isolates but not $\operatorname{Bos}^{\mathrm{S}}$ isolates. Our results supported the recommendation that the conidial germination assay on WA at the discriminatory concentration of $5 \mu \mathrm{g} / \mathrm{ml}$ is a reliable method for phenotyping $B$. cinerea isolates for resistance to boscalid (19).
Furthermore, we developed allele-specific PCR assays for detection of boscalid resistance in $B$. cinerea isolates carrying mutations at the codon position 272 , which would facilitate fungicide resistance-monitoring efforts.

As expected, positive cross resistance had been demonstrated in some SDHIs, such as between flutolanil and carboxin in $C$. cinereus (16) and between boscalid and carboxin in Alternaria

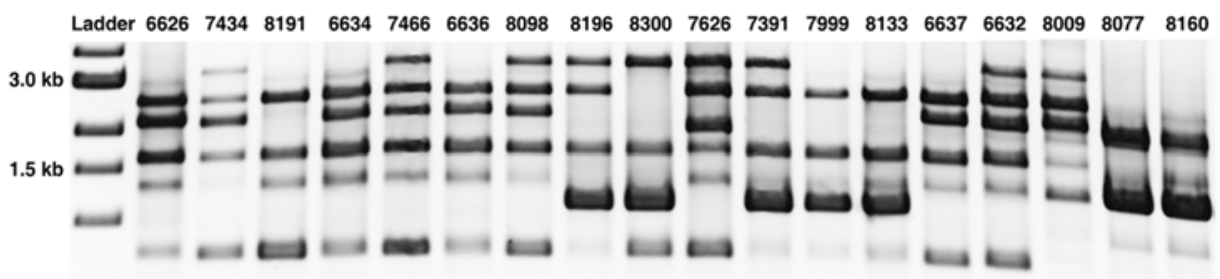

Fig. 4. Electrophoretic separation of DNA fingerprints of Botrytis cinerea isolates amplified by the microsatellite primer (AAC) 5 .

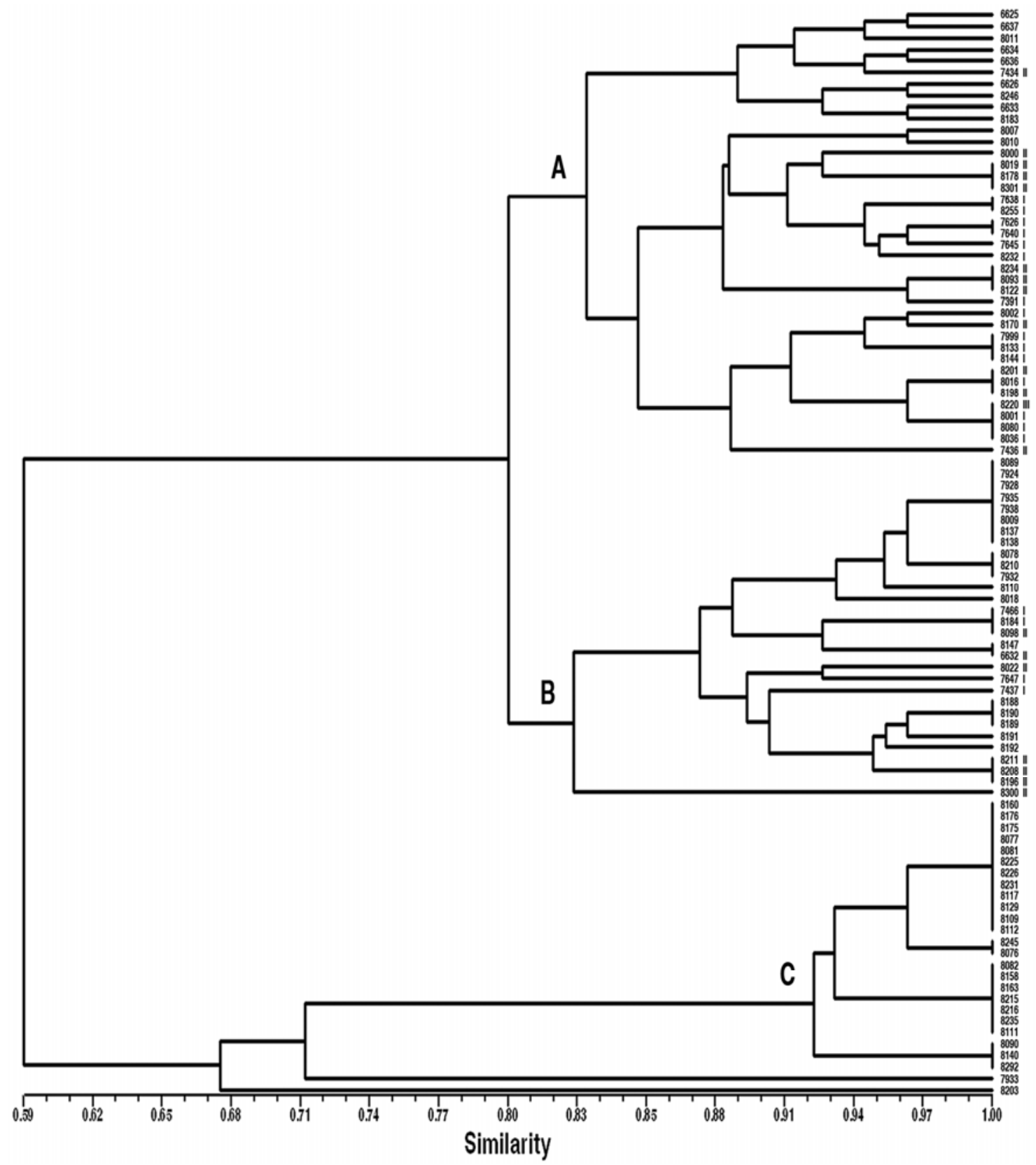

Fig. 5. Unweighted pairgroup method with arithmetic averages cluster analysis of microsatellite-primed polymerase chain reaction data for 95 Botrytis cinerea isolates, including 39 boscalid-resistant isolates (19 type I mutants carrying mutation H272Y in the $B c S d h B$ gene, 19 type II mutants carrying mutation H272R in $B c S d h B$, and 1 type III mutant carrying mutation $\mathrm{P} 225 \mathrm{~F}$ in $B c S d h B$ ), and 56 boscalid-sensitive isolates from apple. 
alternata (3). These reports suggested that boscalid and carboxin may share similar resistance mechanisms in fungal pathogens $(3,16)$. Numerous studies have been done to elucidate molecular mechanisms of carboxin resistance $(2,7,16,26,27)$. Cross resistance between boscalid and carboxin observed in $B$. cinerea in our study further supports our findings that point mutations in $B c S d h B$ are correlated with boscalid resistance in fieldresistant isolates of $B$. cinerea from apple. In recent years, more new SDHI fungicide have been discovered (10) and some of them, such as fluopyram and penthiopyrad, are currently in the process of registration for commercial use in the United States for control of gray mold and other diseases. In A. altanata, Bos ${ }^{\mathrm{R}}$ isolates exhibited cross resistance to penthiopyrad but remained sensitive to fluopyram (1). In $B$. cinerea, negative cross resistance between boscalid and fluopyram has been reported (20). Different cross-resistance patterns between boscalid and other SDHIs suggest that different molecular mechanisms may be involved in resistance to different subclasses of SDHI fungicides. More research is still needed to understand molecular mechanisms of resistance to newly introduced SDHIs. Such information is important to management of SDHI resistance in B. cinerea.

Part of our objective was to determine whether different phenotypes of boscalid resistance (levels of resistance) are associated with particular types of point mutations in $B c S d h B$ among Bos $^{\mathrm{R}}$ isolates. In the present study, $\operatorname{Bos}^{\mathrm{R}}$ isolates were grouped into four resistant phenotypes based on their levels of resistance to boscalid. Our results indicated that, among $\operatorname{Bos}^{\mathrm{R}}$ isolates, $\operatorname{Bos}^{\mathrm{R}}$ phenotypes (levels of resistance) were not associated with particular types of point mutations ( $\mathrm{H} 272 \mathrm{R}$ versus $\mathrm{H} 272 \mathrm{Y}$ ) in $B c S d h B$ because all four $\operatorname{Bos}^{\mathrm{R}}$ phenotypes were present in isolates carrying either the H272R or H272Y mutation. In other words, mutations $\mathrm{H} 272 \mathrm{R}$ and $-\mathrm{Y}$ resulted in phenotypes ranging from low resistance to very strong resistance. Previously, Stammler (28) reported that $\mathrm{Bos}^{\mathrm{R}}$ isolates of $B$. cinerea carrying mutation $\mathrm{H} 272 \mathrm{Y}$ exhibited more pronounced resistance than isolates containing mutation H272R. In contrast, De Miccolis Angelini et al. (8) reported that point mutation $\mathrm{H} 272 \mathrm{Y}$ was correlated with low boscalid resistance in $B$. cinerea but their results were based only on lab UV-induced mutants, whereas Leroux et al. (22) reported that $B$. cinerea isolates carrying $\mathrm{H} 272 \mathrm{Y}$ and $\mathrm{H} 272 \mathrm{R}$ were all moderately resistant to boscalid but their observations were based on a limited number of isolates. The discrepancy between our results and those previously reported could be due to the differences between lab UV-induced mutants and field-resistant isolates, sample sizes, and populations of the pathogen from different crop species in different geographical regions. Different levels of boscalid resistance present among $B$. cinerea isolates carrying mutations at position $225(\mathrm{P} 225 \mathrm{~L} / \mathrm{F} / \mathrm{T})$ have also been reported (28). In our study, only one isolate had the mutation at codon $225(\mathrm{P} 225 \mathrm{~F})$. Thus, we were not able to assess the relationships between the mutations at position 225 and levels of boscalid resistance in field-resistant isolates.

Varying levels of boscalid resistance in isolates within the same mutation type in $B c S d h B$ of $B$. cinerea may be due to the nature of great genetic variability among the isolates of the pathogen (5). In A. alternata, Avenot et al. (3) found no differences in level of boscalid resistance between $\operatorname{Bos}^{\mathrm{R}}$ isolates carrying mutation $\mathrm{H} 277 \mathrm{Y}$ and those carrying mutation $\mathrm{H} 277 \mathrm{R}$ in the $A a S d h B$ gene. However, unlike our study, no differences in level of boscalid resistance were observed in A. alternata within the same mutation type because all isolates were classified highly resistant to boscalid (3). Similarly, no differences in level of carboxin resistance were observed in the mutants of Aspergillus oryzae carrying mutations in the $S d h B$ gene (26). However, mutants carrying mutations in $S d h C$ and $S d h D$ genes exhibited a lower level of resistance to carboxin than the mutants carrying mutations in the $S d h B$ gene. It appeared that a single point mutation in $S d h B$ resulting in varying levels of boscalid resistance (low to strong) may be pathogen dependent.

We detected a high level of genetic variation in populations of $B$. cinerea from apple based on the MP-PCR analysis. Our results were in agreement with previous studies on genetic structure analysis of $B$. cinerea from other crops $(24,25)$. In our study, $B$. cinerea mainly were divided into three groups based on the MPPCR analysis. Bos ${ }^{R}$ isolates were clustered with some $\mathrm{Bos}^{\mathrm{S}}$ isolates into either group A or group $\mathrm{B}$, and no $\mathrm{Bos}^{\mathrm{R}}$ isolates were clustered into group $\mathrm{C}$. This may indicate that the likelihood for the wild-type isolates in groups $\mathrm{A}$ and $\mathrm{B}$ to develop resistance to boscalid is higher than those in group C. However, within Bos $^{R}$ populations, no association was found between types of mutations in the $B c S d h B$ gene and genetic groups based on the MP-PCR analysis because both type I and II mutants were present in either group A or group B. Our results may suggest that the development of resistance to boscalid in B. cinerea likely is not totally random, and resistant populations may come from different specific genetic groups.

\section{ACKNOWLEDGMENTS}

This research was supported, in part, by the Washington Tree Fruit Research Commission. This manuscript is Plant Pathology New Series 0556, Department of Plant pathology, College of Agricultural, Human, and Natural Resource Sciences Agricultural Research Center, Project No. WNP00367, Washington State University, Pullman, WA 99164-6430. We thank Z. Ma for review of the manuscript.

\section{LITERATURE CITED}

1. Avenot, H., and Michailides, T. J. 2009. Monitoring the sensitivity to boscalid of Alternaria alternata populations from California pistachio orchards. (Abstr.) Phytopathology 99:S6.

2. Avenot, H., and Michailides, T. J. 2010. Progress in understanding molecular mechanisms and evolution of resistance to succinate dehydrogenase inhibiting (SDHI) fungicides in phytopathologic fungi. Crop Prot. 29:643-651.

3. Avenot, H. F., Sellam, A., Karaoglanidis, G., and Michailides T. J. 2008. Characterization of mutations in the iron-sulphur subunit of succinate dehydrogenase correlating with boscalid resistance in Alternaria alternata from California pistachio. Phytopathology 98:736-742.

4. Avenot, H., Sellam, A., and Michailides, T. J. 2009. Characterization of mutations in the membrane-anchored subunits AaSDHC and AaSDHD of succinate dehydrogenase from Alternaria alternata isolates conferring field resistance to the fungicide boscalid. Plant Pathol. 58:1134-1143.

5. Beever, R. E., and Weeds, P. L. 2004. Taxonomy and genetic variation of Botrytis and Botryotinia. Pages 29-52 in Botrytis: Biology, Pathology and Control. Y. Elad, B. Williamson, P. Tudzynski, and N. Delen, eds. Kluwer Academic Publishers, Dordrecht, The Netherlands.

6. Brent, K. J., and Hollomon, D. W. 1998. Fungicide resistance: the assessment of risk. FRAC Monograph No. 2. Global Crop Protection Federation, Brussels.

7. Broomfield, P. L. E., and Hargreaves, J. A. 1992. A single amino-acid change in the iron sulphur protein subunit of succinate dehydrogenase confers resistance to carboxin in Ustilago maydis. Curr. Genet. 22:117121.

8. De Miccolis Angelini, R. M., Habia, W., Rotolo, C., Pollastro, S., and Faretra, F. 2010. Selection, characterization and genetic analysis of laboratory mutants of Botryotinia fuckeliana (Botrytis cinerea) resistant to the fungicide boscalid. Eur. J. Plant Pathol. 128:185-199.

9. Drenkard, E., Richter, B. G., Rozen, S., Stutius, L. M., Angell, N. A., Mindrinos, M., Cho, R. J., Oefner, P. J., Davis, R. W., and Ausubel, F. M. 2004. A simple procedure for the analysis of single nucleotide polymorphisms facilitates map-based cloning in Arabidopsis. Plant Physiol. 124:1483-1492.

10. Fungicide Resistance Action Committee. FRAC Code List: Fungicides sorted by mode of action (including FRAC Code numbering). http://www.frac.info.

11. Hagerhall, C., 1997. Succinate: quinone oxidoreductases variations on a conserved theme. Biochim. Biophys. Acta 1320:107-141.

12. Honda, Y., Matsuyama, T., Irie, T., and Watanabe, T. 2000. Carboxin resistance transformation of the homobasidiomycete fungus Pleurotus ostreatus. Curr. Genet. 37:209-212.

13. Horsefield, R., Yankovskaya, V., Sexton, G., Whittingham, W., Shiomi, 
K., Ōmura, S., Byrne, B., Cecchini, G., and Iwata, S. 2006. Structural and computational analysis of the quinone-binding site of complex II (succinate-ubiquinone oxidoreductase): a mechanism of electron transfer and proton conduction during ubiquinone reduction. J. Biol. Chem. 281:7309-7316.

14. Huang, L. S., Sun, G., Cobessi, D., Wang, A. C., Shen, J. T., Tung, E. Y., Anderson, V. E., and Berry, E. A. 2006. 3-nitropropionic acid is a suicide inhibitor of mitochondrial respiration that, upon oxidation by complex II, forms a covalent adduct with a catalytic base arginine in the active site of the enzyme. J. Biol. Chem. 281:5965-5972.

15. Ishii, H., Fountaine, J., Miyamoto, T., Nishimura, K., and Tomita, Y. 2007. Occurrence of a mutation in the succinate dehydrogenase gene found in some isolates of cucumber Corynespora leaf spot fungus resistant to boscalid. (Abstr.) Jpn. J. Phytopathol. 74:38-39.

16. Ito, Y., Muraguchi, H., Seshime, Y., Oita, S., and Yanagi, S. O. 2004. Flutolanil and carboxin resistance in Coprinus cinereus conferred by a mutation in the cytochrome b560 subunit of succinate dehydrogenase complex (complex II). Mol. Genet. Genomics 272:328-335.

17. Jarvis, W. R. 1977. Botryotinia and Botrytis Species: Taxonomy, Physiology and Pathogenicity. Monograph 15. Research Branch Canada, Department of Agriculture, Ottawa, ON, Canada.

18. Keon, J. P. R., White, G. A., and Hargreaves, J. A. 1991. Isolation, characterization and sequence of a gene conferring resistance to the systemic fungicide carboxin from the maize smut pathogen, Ustilago maydis. Curr. Genet. 19:475-481.

19. Kim, Y. K., and Xiao, C. L. 2010. Resistance to pyraclostrobin and boscalid in populations of Botrytis cinerea from stored apples in Washington State. Plant Dis. 94:604-612.

20. Labourdette, G., Lachaise, H., Rieck, H., and Steiger, D. 2010. Fluopyram: efficacy and beyond on problematic diseases. Pages 32-35 in: Modern Fungicides and Antifungal Compounds. H. W. Dehne, K. H. Kuck, P. E. Russell, and H. Lyr, eds. 16th International Reinhardsbrunn Symposium, Firedrichroda, Germany.

21. Leroux, L. 2004. Chemical control of Botrytis and its resistance to chemical fungicides. Pages 195-222 in: Botrytis: Biology, Pathology and Control. Y. Elad, B. Williamson, P. Tudzynski, and N. Delen, eds. Kluwer Academic Publishers, Dordrecht, The Netherlands.

22. Leroux, P., Gredt, M., Leroch, M., and Walker, A. 2010. Exploring mechanisms of resistance to respiratory inhibitors in field strains of Botrytis cinerea, the causal agent of gray mold. Appl. Environ. Microbiol. 76:6615-6630

23. Li, J., Zhou, M., Li, H., Chen, C., Wang, J., and Zhang, Y. 2006. A study on the molecular mechanism of resistance to amicarthiazol in Xanthomonas campestris pv. citri. Pest Manage. Sci. 62:440-445.

24. Ma, Z., and Michailides T. J. 2005. Genetic population structure of Botrytis cinerea from different hosts in California. Plant Dis. 89:10831089.

25. Mu oz, G., Hinrichsen, P., Brygoo, Y., and Griaud, T. 2002. Genetic characterization of Botrytis cinerea populations in Chile. Mycol. Res. 106:594-601.

26. Shima, Y., Ito, Y., Kaneko, S., Hatabayashi, H., Watanabe, Y., Adachi, Y., and Yabe, K. 2009. Identification of three mutant loci conferring carboxin-resistance and development of a novel transformation system in Aspergillus oryzae. Fungal Genet. Biol. 46:67-76.

27. Skinner, W., Bailey, A., Renwick, A., Keon, J., Gurr, S., and Hargreaves, J. 1998. A single amino-acid substitution in the iron-sulphur protein subunit of succinate dehydrogenase determines resistance to carboxin in Mycosphaerella graminicola. Curr. Genet. 34:393-398.

28. Stammler, G. 2008. Mode of action, biological performance and latest monitoring results of boscalid sensitivity. Pages 30-43 in: Abstr. 18th Symp. Res. Committee on Fungicide Resistance. The Phytopathological Society of Japan, Matsueshi, Japan.

29. Sun, F., Huo, X., Zhai, Y., Wang, A., Xu, J., Su, D., Bartlam, M., and Rao, Z. 2005. Crystal structure of mitochondrial respiratory membrane protein complex II. Cell 121:1043-1057.

30. Xiao, C. L., and Boal, R. J. 2009. Preharvest application of a boscalid and pyraclostrobin mixture to control postharvest gray mold and blue mold in apples. Plant Dis. 93:185-189.

31. Zhang, C. Q., Yuan, S. K., Sun, H. Y., Qi, Z. Q., Zhou, M. G., and Zhu, G. N. 2007. Sensitivity of Botrytis cinerea from vegetable greenhouses to boscalid. Plant Pathol. 56:646-653.

32. Zhu, L. X., Zhang, Z. W., Liang, D., Jiang, D., Wang, C., Du, N., Zhang, Q., Mitchelson, K., and Cheng, J. 2007. Multiplex asymmetric PCR-based oligonucleotide microarray for detection of drug resistance genes containing single mutations in Enterobacteriaceae. Antimicrobiol. Agents Chemother. 51:3707-3713. 